\title{
First report of citrus blackfly (Hemiptera: Aleyrodidae) in the state of Piauí, Brazil
}

\author{
Silva, JDC. ${ }^{a}$, Beserra-Junior, JEA. ${ }^{a *}$, Girão-Filho, JE. ${ }^{a}$, Silva, RBQ. ${ }^{b}$, \\ Medeiros, WR. ${ }^{a}$, Carvalho, DS. ${ }^{a}$ and Silva, PRR. ${ }^{a}$ \\ ${ }^{a}$ Departamento de Fitotecnia, Centro de Ciências Agrárias, Universidade Federal do Piauí - UFPI, \\ CEP 64049-550, Teresina, PI, Brazil

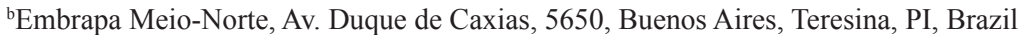 \\ *e-mail: evando@ufpi.edu.br
}

Received: May 12, 2014 - Accepted: November 24, 2014 - Distributed: May 31, 2015

(With 1 Figure)

The citrus blackfly Aleurocanthus woglumi Ashby 1915 (Hemiptera: Aleyrodidae) is an important insect species native to southwest Asia and represents one of the main pests of citrus plants. It is widely distributed in the tropical and subtropical regions of the globe (Heu and Nagamine, 2001). In Brazil, A. woglumi was first reported in the state of Pará in 2001 (Silva, 2005). Since then, the presence of the insect has been confirmed in several Brazilian states (Brasil, 2008). Because of its widespread geographical presence, $A$. woglumi is no longer considered an A2 quarantine pest (Pena et al., 2009).

The insect causes direct damage to the plants by sucking the sap and weakening it, thereby inducing wilt, which often leads to the plant's death. It also causes indirect damage by its excretion, which favors the development of sooty mold (Capnodium sp.) that completely coats the leaf, resulting in reduction of photosynthesis and impairing plant respiration (Oliveira et al., 2001). Citrus blackfly attack can reduce fructification by up to $80 \%$ (Barbosa et al., 2004). It is a pest with polyphagous feeding habits; the literature shows more than 300 species of host plants for this insect. Among the various host plants, $A$. woglumi prefers plants of the citrus species (Lopes et al., 2013). It is worth noting that this insect has a high degree of adaptability, because it can survive in different weather conditions, as understood from the regions where it has been found (Heu and Nagamine, 2001).

The occurrence of $A$. woglumi for the first time in Piauí was observed since September 2010 in a phytosanitary inspection by Agência de Defesa Agropecuária do Piauí (ADAPI), in commercial and home orchards in the municipalities of Altos, Amarante, Angical do Piauí, Barro Duro, Esperantina, Lagoa do Piauí, Piracuruca, Regeneração, Ribeiro Gonçalves, Santa Filomena, Teresina, Uruçuí and Valença do Piauí (ADAPI, personal communication). In November 2012 and in February 2013 A. woglumi observations were conducted in the municipalities of Teresina and Angical do Piauí, respectively, which were orange orchards of small areas. The leaves of infested plants were examined under a stereoscopic microscope, which confirmed the presence of eggs, nymphs, pupae, and adults of Aleurocanthus sp., identified based on their morphological characteristics as shown in the literature (Nguyen and Hamon, 2003). Infested leaf samples (Figure 1a) were sent to the Instituto Biológico of São Paulo to confirm the identity of the insect at the species level. The cream-white eggs were laid in a spiral (Figure 1b). Eggs with dark colors were found, probably, toward the advanced stages of maturation. Nymphs at different stages of development (Figure 1c), pupae, and adults were also found on the young branches (Figure 1d).

A. woglumi has spread easily since it was first identified in the country in 2001 (Silva, 2005). Among the states that border Piauí, the insect has already been recorded in Maranhão, Tocantins, Pernambuco and Ceará (Lemos et al., 2006; Brasil, 2008; Monteiro et al., 2012).

To our knowledge, this is the first study to show the occurrence of $A$. woglumi in the state of Piauí, colonizing avocado, mulberry, orange, lemon, mango, pomegranate and tangerine trees. Considering the destructive ability of the citrus blackfly, it is necessary to adopt effective programs for managing the insect in the state of Piauí, to reduce the population and spread of this insect.

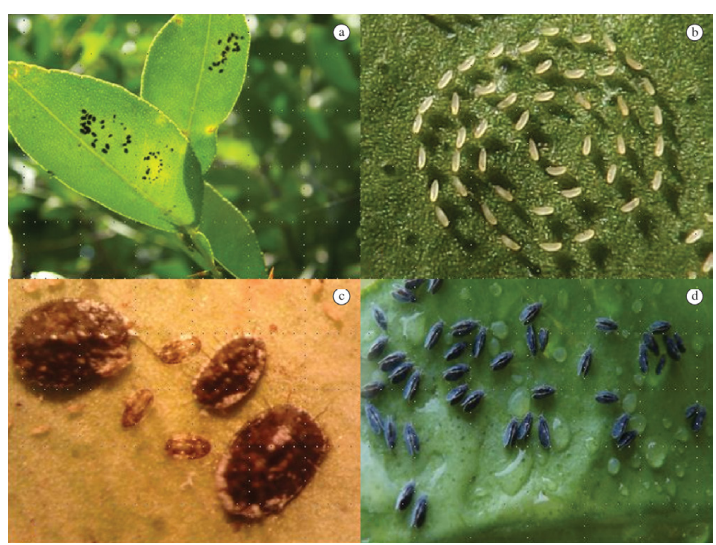

Figure 1. Citrus blackfly (Aleurocanthus woglumi) at different stages of development. a: Citrus leaves showing signs of infestation; b: Cream-white eggs in a spiral arrangement; c: Nymphs at different stages of development; and d: Adult insects. 


\section{References}

BARBOSA, FR. and SANTANA, MRSP., SILVA, CSB. and PARANHAS, BJ., 2004. Aleurocanthus woglumi (Hemiptera: Aleyrodidae): uma ameaça à fruticultura do Vale do São Francisco. In Anais do XX Congresso Brasileiro de Entomologia, 2004. Gramado. Gramado: Sociedade Entomológica do Brasil.

Brasil. Ministério da Agricultura - MAPA, 2008. Instrução Normativa 23, de 29 de abril de 2008. Restringe o trânsito de plantas e suas partes, exceto sementes e material in vitro, das espécies hospedeiras da mosca negra dos citros (Aleurocanthus woglumi) constantes da lista oficial de Pragas Quarentenárias Presentes no Brasil, quando oriundas de Unidades da Federação (UF) onde seja constatada, por laudo laboratorial, a presença da praga. Diário Oficial da União, Brasília, 2 mai. Seção 1, p. 2.

HEU, RA. and NAGAMINE, WT., 2001. Citrus blackfly, Aleurocanthys woglumi Ashby (Homoptera, Aleyrodidae). New Pest Advisory, vol. 99.

LEMOS, RN., SILVA, GS., ARAÚJO, JR., CHAGAS, EF., MOREIRA, AA. and SOARES, ATM., 2006. Ocorrência de Aleurocanthus woglumi Ashby (Hemiptera: Aleyrodidae) no Maranhão. Neotropical Entomology, vol. 35, no. 4, p. 558559. http://dx.doi.org/10.1590/S1519-566X2006000400021. PMid:17061808

LOPES, GS., LEMOS, RNS., ARAÚJO, JRG., MARQUES, LJP. and VIEIRA, DL., 2013. Preferência para ovoposição e ciclo de vida de mosca-negra-dos-citros Aleurocanthus woglumi Ashby em espécies frutíferas. Revista Brasileira de Fruticultura, vol. 35, no. 3, p. 738-745. http://dx.doi.org/10.1590/S0100-29452013000300010. http://dx.doi.org/10.1590/S0100-29452013000300010

MONTEIRO, BS., RODRIGUES, KCV., SILVA, AG. and BARROS, R., 2012. Ocorrência da Mosca-Negra-dos-Citros (Aleurocanthus woglumi Ashby) (Hemiptera: Aleyrodidae) em Pernambuco. Revista Caatinga, vol. 25, no. 2, p. 173-176.

NGUYEN, R. and HAMON, AB., 2003. Citrus blackfly, Aleurocanthus woglumi Ashby (Homoptera: Aleyrodidae). University of Florida Cooperative Extension Service, Institute of Food and Agriculture Sciences, EDIS. CIR 360.

OLIVEIRA, MRV., SILVA, CCA. and NÁVIA, D., 2001. Mosca negra dos citros Aleurocanthus woglumi: alerta quarentenário. Brasília: Ministério da Agricultura, Pecuária e Abastecimento.12 p.

PENA, MR., SILVA, NM., VENFRAMIM, JD., LOURENÇÃO, AL. and HADDAD, ML., 2009. Biologia da Mosca-Negra-dos-Citros, Aleurocanthus woglumi Ashby(Hemiptera: Aleyrodidae), em três plantas hospedeiras. Neotropical Entomology, vol. 38, no. 2, p. 254-261. http://dx.doi.org/10.1590/S1519-566X2009000200014. PMid:19488516

SILVA, AB., 2005. Mosca Negra dos Citros, Aleurocanthus woglumi Ashby, praga potencial para a citricultura brasileira. In POLTRONIERI, LS., TRINDADE, DR. and SANTOS, IP. (Eds.). Pragas e Doenças de Cultivos Amazônicos. Belém: Embrapa Amazônia Ocidental. p. 147-156. 